\title{
The Roles of Parents in Enhancing Academic Performance among Public Secondary Schools at Nyamagana District, Tanzania
}

\author{
Peter Adam Seni and Daniel Onyango, PhD \\ St. Augustine University of Tanzania \\ Corresponding Email: seniadam92@gmail.com
}

\begin{abstract}
This study sought to investigate on the roles of parents in enhancing children's academic performance among Public Secondary Schools at Nyamagana District, Tanzania. The study employed the mixed research approach to organize the qualitative and quantitative data so as to deal with the research problem. The sample for this study included 88 students whereby Simple random sampling was used to select them. Purposive sampling was used to select the DEO, WEO and some teachers while parents were selected through convenient sampling. Data was gathered through questionnaire and interview schedule. The instruments were validated by two research experts from Saint Augustine University of Tanzania. The study concludes that parents are somehow not doing very well on the issue of parenting as a good number of them did not play their role effectively. Parental role in communication with teachers was done well as a good number of parents rarely or never communicated with teachers to make follow ups regarding their children's education. The rate of parents' volunteering in school development activities was very low and the rate of parental participation in supervision of students' learning at home was very minimal. However, parents participated in decision making regarding school related activities. Finally, parents were not doing well on issues related to community participation. Based on the conclusions, it is recommended that since the rate of parental participation in enhancing children's academic performance is low, school authorities need to organize for seminars and workshops to parents on the importance of their participation in school related programs that enhance the academic performance of their children.
\end{abstract}

Key word: Parenting, communication, volunteering, collaboration, academic performance

\section{Introduction}

Parental involvement in children's academic affairs is a key aspect for the academic development of secondary schools. This study defines parental role in education as that of helping children with their homework, purchasing school uniforms, buying learning resources for the children, communicating with the school, attending school activities that are relevant to school performance and having high expectations for the children's progress. Parents are expected to be concerned about their children's academic performance and showing dedication in their children's learning through availing themselves during parents' meetings in order to gain a better understanding of the performance of their children. Parents can also make follow-ups with their children's subject teachers in order to identify areas where the children are facing challenges (Clinton \& Hattie, 2013).This means that parents can go to the extent of contacting their teachers, thus building and strengthening the relationship between the learner and the teacher which indicates their commitment towards their children's learning.

When it comes to children's education, there are some factors which must be considered such as parenting, communicating, supervision of learning at home, decision-making and collaborating with the schools and community. These factors contribute to the academic performance of the learners (Epstein, 2009). Parental involvement guarantees a good and conducive climate for social, intellectual and emotional development of a child as well as love, security, guidance and care that may contributes to good academic performance.

In the $20^{\text {th }}$ century, United States of America was among the first countries in the world to involve parents in their children's education from early 
childhood education whereby parent cooperative nursery schools bloomed from the 1920s to the 1960s. Most of these educational centers were located in colleges or suburban towns and welcomed primarily stay-at-home mothers who served as paraprofessionals in the classrooms, assisting teachers and taking care of the children Tekin, 2014. The major notion of involving parents was that parents know the needs of the children and therefore should be involved in the school programs. Parental involvement in school helped those educational institutions to reduce their operational costs and build a tie between parents and schools (Gestwicki, 2015).

Wright and Hartle (2007) as cited in Hakymez (2014) showed that after the World War II, various programs were initiated that supported parental involvement such as parental self-development training and learning. The extensive parental involvement was introduced via Head Start in the 1960s and 1970s Head Start program was designed for particularly disadvantaged families and was required to ensure the utmost level of participation by the families (Goldberg, 1997).

The main philosophy of the Head Start program was that parents were equal partners with education professionals (Zigler, 1992). Both parents and teachers were considered to be experts in handling children, each bringing different types of expertise (Gestwicki, 2015).The parental involvement in United States of America was based on getting parents together with teachers so as to ensure that children learn effectively for their future development. Parents decided on a level of their involvement. Furthermore, parents were offered education on how to engage in assisting their children (Kellaghan, Sloane, Alvarez, \& Bloom, 1993). For example, parents began to work with their own children along with the staff, plan activities by themselves, participate as volunteers in classrooms and set standards for the hiring of professional staff (Steine, Melanie \& Thorkildsen, 1999).

In Turkey, parental involvement in children's education occurred even in the Ottoman periods. In the Sıbyan Schools, for example, which was an educational setting for young children, parental involvement took place mostly in fundraising and volunteering activities related to school maintenance. After the collapse of the Ottoman State and establishment of the Turkish Republic, the educational system went through a number of reforms as an important aspect of the westernization process. Educational settings, programs and activities were regulated by the Ministry of National Education (MONE). The MONE predominantly controlled the parental involvement programs and mandated every school to form a School Family Association (SFA). Parental involvement in Turkish schools through SFAs included the following types of activities: assisting in school, volunteering, parental education, parentteacher conferences, organizing events for parents and students, parent-to-parent communication and training activities, fund-raising activities, collaborating with the other agencies to improve the opportunities in schools, communicating with alumni and so on (Hakymez, 2015). There were special programs formulated to monitor parental involvement in children's education.

In Africa, the issue of parental involvement has been taken seriously in some countries though its progress is not as expected. In South Africa, for instance, there is an educational transformation which is associated with parental involvement rather than their exclusion. Following the 1994 democratic elections, a new educational system was established in order to create equity amongst all racial groups in South Africa. In order for this to be successful, a National Department and nine provincial departments of education were established. Parental involvement in their children's schooling was encouraged through legislations such as the South African Schools Act in 1996 (South Africa, DoE, 1996). The Act made a conducive environment for the parents to involve effectively and become important partners in the education of their children. The South African School's Act (SASA) 84 of 1996 provided opportunities for parental involvement in their children's schooling in different ways including assistance with fund-raising events, helping with the management of school resources, infrastructural development and school maintenance. The new Curriculum and Assessment Policy Statement (CAPS) also stipulates that parents and the community have an important role to play in curriculum management (Singh, Mbokodi and Msila, 2004).

Unlike South Africa, in Nigeria, despite the fact that provision has been made for parental involvement in education policy, its actualization remains minimal (Labo-popoola, Bello \&Atanda, 2009, p.254 as cited by Obayopo, 2017). The Nigerian 
government launched the Universal Basic Education (UBE) program in 1999 (Feese, 2011). In the Nigerian educational context, Parent Teachers Associations (PTA) facilitated parental involvement and ensured that civil society supports the government to give all Nigerian children access to quality education.

In Kenya, the government has acknowledged the need to improve the learning environment by involving parents. National Council for Law Report (2013) was enacted necessitating the school Boards of Management to evaluate school needs with full participation of parents. Thus, in Kenya, parents have been involved and the government passed an Act which states that there should be full participation of parents in education for future development. However, despite the existence of such law in Kenya, parents still do not understand their role in enhancing academic performance of their children.

The tendency of parental involvement of children's education in Tanzania is similar to Kenya to some extent. In 1978, the government passed an Education Act to make education mandatory for children aged between 7 and 13. However, the actual enrollment levels have fluctuated since then from $70 \%$ to $95 \%$ due to a number of factors including concerns over education quality in the context of a struggling national economy (AlSamarrai and Peasgood (1998) as cited in Langat (2014).

However, increased interactions at the local, national and global context levels have paved way for changes in Tanzania's education policy in the recent years. As a result, the government of Tanzania introduced the Primary Education Development Plan (PEDP) in 2002 aiming at materializing Tanzania's commitment toward the global Education for All (EFA) targets articulated by the international community in Jomtien and Dakar (United Republic of Tanzania, 2005). The main priority of the PEDP is to increase overall enrolment of girls and boys in schools. Core government strategies for achieving this goal include abolition of school fees and information campaigns aiming at increasing awareness on the importance of education.

In 2004, the government of the United Republic of Tanzania launched a Secondary Education Development Program (SEDP) with the aim of improving access to secondary education; this reform aimed at materializing Tanzania's commitment towards the global Education for All (EFA) (United Republic of Tanzania, 2005). Furthermore, the education sector was struggling with severe quality deficiencies (Makoye, 2014). Community participation in education also increased during this time than before, which means the government noticed how parental involvement in education can be the way forward to improve academic performance of students.

According to Right to Education Initiative (2018), to ensure that there is improvement on the issue of education, Tanzanian government came up with the policy of providing free basic education in 2015. The provision of free Education is the response to various education and development policies such as the Education and Training Policy of 2014 and the Tanzania Development vision of 2025. According to the policy, basic education shall be free and compulsory with single textbooks for all schools and shall provide quality education which is recognized across the region and the world. In many developing countries like Tanzania, parents spend a significant amount of their income to send their children to school. Although in most of these countries governments were responsible in paying teachers' salaries, schools were dependent on school fees and contributions for construction and carrying out school routines. Therefore, due to the provision of free education, it has become easy for parents to support their children on academic performance than before.

Parental prospects that stalk from their beliefs and practices have been a dominant predictor of achievement. Parental expectations and expressions of confidence in their children's abilities and talents are paramount in promoting the potential that the children have toward academic achievement. Consequently, the nature and extent of parental involvement at home and at school play a crucial role in the development of their children's academic potentials. Therefore, parental aspirations and expectations should be communicated either implicitly or explicitly to their children in their everyday interactions, which then directly or indirectly determine the way the children perceive education and perform at school (Hayes, 2012).

Nyamagana District is not isolated from other places in Tanzania where academic performance of some of the children is a crisis. (Makoye (2014) indicates that social economic status of the parents at 
Nyamagana District has got a relationship with students' academic performance. Thus, Parents need to know their children's progress at school by involving themselves at home and by participating in schools with teachers so as to enhance children's academic performance. Low socioeconomic status strongly affected the achievement of students, dragging them down to poor academic performance. Makoye further indicated that parents with low level of education may have limited follow up to their children pointing to a possibility of poor academic performance. Furthermore, children of illiterate homes are likely to perform worse than their counterparts.

Agabrian (2007) as cited in Bunijevac and Durisic (2017) argued that it is true, educators cannot do it alone and therefore there is a need for parental involvement toward children's academic performance. Parents have a very important role to play in the education of their children because they act as the mediators between students and the school. Parental involvement would consequently elevate not just children's cultural identity but would also facilitate their socialization, improving their attitudes and behavior towards those around them within and outside their communities. Parents are the ones who can shape the behavior of their children and make them to behave according to moral standards of the society. Therefore, the government and policy makers should recognize that parents are the first and important teacher; hence they need to participate actively in their children's academic performance.

Mariba (2017) conducted a study on parental role in Tarime District. One of the objectives of the study was to find out the perception of parents towards academic performance of their children in secondary schools. The researcher found out that majority of parents were only concerned about their children attending school. It is also evident that majority of parents were aware of priority in skills development as a key strategy for economic competitiveness and growth. From the study, it was recommended that parents should support their children in various schools matters.

Shija (2017) assessed parental participation in academic performance in Tanzania. The findings revealed that there is poor engagement of parents in education, which has led to poor academic performance. The study came up with some appropriate measures to be adopted to ensure effective participation of parents so that to improve academic performance. The mechanisms include schools communicating with parents, establishment of parents -teachers associations and eradicating negative cultural values.

According to Singh and Msila (2004), one of the challenges that hamper effective parental involvement is low income. This leads them to engage in more jobs and spend less time at home helping their children with their school work. Consequently, the schools sometimes fail to create strong links between homes and schools. Also some parents are not able to read and write which makes it difficult for them to assist their children with their homework (Lemmer, 2012). Social cultural issues like gender preferences may also prevent parents from participating in education based on parents 'values and beliefs. This makes it difficult for the parents to play their role of enhancing children academic performance.

\section{Research Methodology}

This part explains the methodology employed for this study. It highlights on such issues as research design, population and sampling, treatment of data and ethical considerations.

\section{Research Design}

The study employed mixed the research approach to organize the qualitative and quantitative data so as to deal with the research problem. Descriptive research design was used in recording, analyzing and interpreting the quantitative data while the thematic approach was used to present the qualitative data.

\section{Population and Sampling}

The sample for this study included 88 students from three secondary schools whereby Simple random sampling was used to select them. Purposive sampling was used to select the DEO, WEO and teachers while parents were selected through convenient sampling procedures.

\section{Instruments and Validation}

Data was gathered through a questionnaire and the interview schedule. The instruments were validated by two research experts from Saint Augustine University of Tanzania, Mwanza.

\section{Ethical Considerations}

The researchers followed ethical procedures such as obtaining permission from government authorities in Nyamagana District prior to data collection. 


\section{Results and Discussion}

The objective of this study was to examine parental involvement in enhancing children's academic performance in terms of six aspects among public secondary schools at Nyamagana District. Closedended items were provided in the questionnaire for participants to fill as seen in table 1

Table 1: Parental Involvement

\begin{tabular}{|c|c|c|c|c|c|c|c|c|c|c|}
\hline \multirow[t]{2}{*}{ Parenting Aspect } & \multicolumn{2}{|c|}{ Never } & \multicolumn{2}{|c|}{ Rarely } & \multicolumn{2}{|c|}{ Sometimes } & \multicolumn{2}{|c|}{ Frequently } & \multicolumn{2}{|c|}{ Very Frequently } \\
\hline & $\mathrm{F}$ & $\%$ & $f$ & $\%$ & $f$ & $\%$ & $f$ & $\%$ & $f$ & $\%$ \\
\hline Parenting & 14 & 18.4 & 14 & 18.4 & 21 & 27.6 & 13 & 17.0 & 14 & 18.4 \\
\hline Communicating & 34 & 35.0 & 7 & 8.0 & 28 & 37.0 & 7 & 9.0 & 0 & 0.0 \\
\hline Volunteering & 55 & 72.0 & 14 & 18.0 & 7 & 10.0 & 0 & 0.0 & 0 & 0.0 \\
\hline Learning at Home & 28 & 37.0 & 28 & 37.0 & 20 & 26.0 & 0 & 0.0 & 0 & 0.0 \\
\hline Decision Making & 21 & 28.0 & 7 & 9.0 & 41 & 54.0 & 7 & 9.0 & 0 & 0.0 \\
\hline Collaborating with Community & 21 & 28.0 & 28 & 37.0 & 27 & 35.0 & 0 & 0.0 & 0 & 0.0 \\
\hline
\end{tabular}

\section{Parenting}

Table 1 shows that, 14 (18\%) of respondents indicated that parents do not participate well in parenting while 14 (18\%) indicated that parents rarely participate. Additionally, 21 (28\%) indicated that parents sometimes participate in parenting while $13(17 \%)$ indicated that parents frequently participate and only $14(18 \%)$ reported that parents participate very frequently in parenting. The finding suggest that parents are somehow not doing very well on the issue of parenting as a good number of parents do not play their parenting role effectively, which may hinder the effective academic performance of the children.

\section{Communicating}

Table 1 further indicates that, 34 (35\%) respondents reported that parents never engage in communication while $7(8 \%)$ reported that parents rarely communicate. On the other hand, $28(37 \%)$ reported that parents sometimes communicate while only $7(9 \%)$ reported that parents frequently communicate. The findings indicate that parental role in communication with teachers is also not done very well as a good number of parents (43\%) rarely or never communicate with teachers to make follow up of their children's education. As the result, this may affect academic performance of the children.

The lack of parental involvement in communication was also indicated through the interview with teachers, as one of the class teachers revealed that:

Parents do not effectively cooperate with teachers. Most of them seem to lose hope and some of them are very lezzy. As the class teacher, I receive very little support from parents and when I call them to come so as to discuss different matter concerning students' academic performance, most of them don't show up (Teacher at school A).

According to Shija (2017), poor communication of the parents leads to poor academic performance. This led Lemmer (2007) to advise that school committees should establish effective communication strategies between the schools and parents. By doing so, academic performance of the students will be improved.

\section{Volunteering}

Table 1 further shows that $72 \%$ of respondents reported that parents never volunteered at school activities while $18 \%$ reported that parents rarely volunteer at school activities. Only $9 \%$ of respondents indicated that parents sometimes volunteer. This suggests that the rates of parents volunteering in school development activities is very low and needs special attention. This was further emphasized by one of the respondents through interview: "When parents are asked to volunteer in school activities, most of them never respond. When they are asked to provide reasons, most of them say, they are busy in economic activities so as to generate money for their families" (At school B). While volunteering activities are created to enable schools and community including parents to socialize and work together for the common goal of enhancing children's academic performance, parents need to volunteer and be part of the school project activities. According to Bandura (1997), socialization is the agency of developing human behavior, and therefore parents as part of the society should be a good example to their children by volunteering in different activities which will make students to learn from them. In that way, students will be prepared to be active members in various aspects of community development. 


\section{Learning at Home}

Supervision of learning at home is another important aspect of parental engagement. As reflected in Table 1, 37\% of respondents indicated that parents never participate in supervision of students' learning at home while another $37 \%$ revealed that parents rarely participate in the exercise. Only $26 \%$ of respondents indicated that parents sometimes participate in supervision of students' learning at home. Therefore, majority of respondents revealed that the rate of parental participation in supervision of students' learning at home is very minimal despite the fact that participating in learning at home is very important since it enables parents to be closer to their children and at the end helps to improve children's academic performance. This finding was further supported by information from the interview schedule whereby one of the teachers revealed that:

Parents are not effectively involved in the learning process of their children at home, and this is due to the fact that most of them are very busy with economic activities, forgetting that they have also a responsibility of helping their children so as to be able to improve their academic performance (Teacher at school D).

\section{Decision Making}

Another aspect for parental involvement is decision making whereby $54 \%$ of respondents indicated that parents sometimes participate in decision making while $28 \%$ indicated that parents never participate in decision making, 9\% indicated that parents rarely participate and $9 \%$ indicated that parents frequently participate in decision making. This suggests that parents somehow participate in decision making regarding school related activities as majority of respondents admitted that the parents sometimes do participate. Through the interview with teachers, one of the teachers revealed that:

The issue of parental participation on decision making in my school is a problem as they sometimes participate but the majority of them do not. This trend affects our school because we need parents to be part of our decisions so as we can improve students' academic performance together (Teacher at school C).
The interview with the DEO further revealed that "when parents are asked to attend school meetings, they always provide reasons for not attending and as a result, the school administration alone makes decisions that touch the lives of the students." Therefore, authorities need to create atmosphere for parents to attend school meetings to air out their views and suggestions on the development of the schools. This is supported by Epstein (2009) who argued that involving parents in governance and decision-making is yet another strategy for stimulating links between schools and parents.

\section{Collaboration with Community}

Table 1 further show the rate of parents' collaboration with the community whereby $28 \%$ of respondents revealed that parents never collaborate while $37 \%$ indicated that parents rarely collaborate with the community. Furthermore, only $35 \%$ indicated that parents sometimes collaborate with the community. These results indicate that parents are not doing well on issues related to community participation even though there are many things which parents should work together with the community which are related with academic performance of the students. These include building classrooms and toilets, buying learning materials and solving different problem related to education.

\section{Conclusions and Recommendations}

This part presents the conclusions and then gives the recommendations of the study.

\section{Conclusions}

The study concludes that parents are somehow not doing very well on the issue of parenting as a good number of them did not play their role effectively, which may hinder the effective academic performance of the children. Parental role in communication with teachers is also not done well as a good number of parents or never communicated with teachers to make follow ups regarding their children's education.

Furthermore, the rate of parents' volunteering in school development activities was very low and needs special attention. The rate of parental participation in supervision of students' learning at home was very minimal despite the fact that participating in learning at home is very important since it enables parents to be closer to their children and at the end helps to improve children's academic performance. Parents participated in decision 
making regarding school related activities as majority of respondents admitted that the parents sometimes do participate.

Finally, parents are not doing well on issues related to community participation even though there are many things which parents should work together with the community which are related with academic performance of the students.

\section{Recommendations}

Based on the conclusions of the study, it is recommended that since the rate of parental participation in enhancing children's academic performance is low, school authorities need to organize for seminars and workshops to parents on the importance of their participation in school related programs that enhance the academic performance of their children.

\section{Reference}

Bandura, A. (1997). Self efficacy: the exercise of control. New York: W. H. Freeman \& Company.

Bunijevac, M. \& Durisic, M. (2017). Parental Involvement as Important Factor for Successful Education. C.E.P.S Journal, 7(3), 37-153.

Clinton, J., \& Hattie, J. (2013). New Zealand students' perceptions of parental involvement in learning and schooling: Asia Pacific Journal of Education, 33(3), 324-337.

Epstein J. (2009).Perspectives and previews on research and policy for school, family, and Community partnerships. In: Booth A, Dunn JF, editors. Family-school links: How do they affect educational outcomes? Erlbaum; Mahwah, NJ: 1996.

Feese, N.S. (2011). Strengthening the role of parent teaching association in education governance in Nigeria. The steering committee in developing the common wealth education fund, CEF strategy in Nigeria. CEF Newsletter, 17 December, 2011.

Fishel, M., \& Ramirez, L. (2005). Evidence-based parent involvement interventions with school-aged children: School psychology quarterly, 20(4), 371-402.

Hakymez, S. (2015). Turkish Early Childhood Educators in Parental Involvement.
European Educational Journal, 14 (5), 100112. DOI: $10.1177 / 1474904114565152$.

Hayes, D. (2012). Parental Involvement and achievements outcomes in African American Adolescents. Journal of Comparative Family Studies, 43 (4), 567-582. Retrieved from https://psycnet.apa.org/record/201327688-008\&ved

Gestwicki, C. (2015). Home, school, and community relations: Boston:Cengage Learning.

Goldberg, S. (1997). Parent Involvement Begins at Birth: Collaboration between Parents and Teachers of Children in the Early Years. Allyn and Bacon/Simon and Schuster Education Group, 160 Gould Street: Needham Heights, MA 02194-2315.

Hung, C. L. (2007). Family, schools and Taiwanese children's research, 49(2), 115-125.

Kellaghan, T., Sloane, K., Alvarez, B., \& Bloom, B. S. (1993). The home environment and school learning: Promoting parental involvement in the education of children. California:JosseyBass.

Langat, B. K. (2014). Parental Perception on Selected Factors on Academic Performance in Public Primary Schools in Kamosa Division of Nakuru County, Kenya. (Masters Dissertation, Egerton University, Kenya). Retrieved from https://irlibrary.egerton.ac.ke/ispui/bitstream/12345 $6789 / 1547$.

Lemmer, E. M. (2007). Parent involvement in teacher education in South Africa: International Journal about parents in education, 1(0), 218-229.

Lemmer, E. M. (2012). Who's doing the talking? Teacher and parent experiences of parentteacher conferences: South African journal of education, 32(1), 83-96.

Mariba, E. (2017).Parents' role in children's learning: a case of secondary schools in Tarime district in Tanzania.

Makoye, S. (2014). Assessment of Students' Academic Performance under Secondary Development PIn (SEDP 1) Implementation: the Case of Nyamagana District. (Masters Dissertation, Sokoine University of 
Agriculture). $\quad$ Retrieved from http://www.susire.sua.ac.tz/bitstream/hand le/123456789/619/suzan.

National Council for Law Report. (2013). the Basic Education Act of Kenya. Retrieved from https://ilo.org>docs>KEN94495.

Obayopo, R. (2017). Parental involvement in primary schools in Nigeria:University of South Africa.

Right to Education Initiative (2018). Tanzania Implements Free Education Policy for Secondary Education. Retrieved from www.right-to-education.org

Singh, P., Mbokodi, M.S. \& Msila, T.V. (2004). Black Prental Involvement in Education. South African Journal of Education. 24 (4). 301307. Retrieved from https://www.ajol.info./index.php/saje/articl e/view.

Shija, D. (2017). Assessment of parents participation in academic performance in public secondary schools in Tanzania: A Case of Chamwino District Council in Dodoma Region. Retrieved from http://hdl.handlenet/20.500.126611489

Steine, S., Melanie, R. \& Thorkildsen,R. J. (1999). Parent Involvement in Education: Insights and Applications from Research. Research for the Practitioner Series. p. 94. Retrieved from https://eric.gov/?id=ED467175.

Tekin, K.A. (2014). Parent Involvement Revisited: Background, Theories, and Models. IJAES. 11 (1). $1 . \quad$ Retrieved from https://www.researchgate.net/publication/ 268079028

United Republic of Tanzania (2005).National Strategy for Growth and Reduction of Poverty (NSGRP): Dar es Salaam. URT.

Zigler, E. F., \&Muenchow, S. (1992). Head Start: The inside story of America's most successful educational experiment. New York: American Education. 